\title{
Technology-Enhanced Business English Writing Teaching
}

\author{
Dan Li and Binrong Chen
}

\begin{abstract}
The paper aims to present a design and an evaluation of a Business English Writing lesson with the support of several technologies, namely, webQuest, teaching blogs and concordancers (language corpora) in a specific context. This is likely to give an insight into how Chinese vocational college students develop their business writing skills by utilizing internet resources under the guidance of teachers in the era of globalization and information.
\end{abstract}

Index Terms-Business English writing, technology tools, internet resources, in the era of globalization and information.

\section{INTRODUCTION}

In the era of information, the application of Internet technologies in international transactions has led to a dramatic growth of Internet-based business. Therefore, how to apply the technology properly is suggested to be part of the teaching content in business English. As the core module in a Business English program, the importance of business English writing has long been recognized. However, some relevant surveys indicate that Business English Writing is considered the most difficult course in the program and learners appear to mechanically rely on a number of model samples provided by teachers, which makes the writing module unattractive to learners and teachers. Hence, how to inspire students' interest in writing and improve the teaching efficiency are the main concerns in the study.

The paper starts with an introduction of a teaching context from both macro and micro perspectives. It is followed by a literature review in which the pedagogical and theoretical frameworks are clarified to support the subsequent teaching design. Then the lesson plan and design rationale are described. The last part includes an evaluation and the reflection on the lesson design and a conclusion.

\section{TEACHING CONTEXT}

\section{A. Macro Context}

Outline of China's National Plan for Long- and Medium-Term Education Reform and Development 2010-2020 (National Education Plan) appeals to informatization in education; thus the importance of applying information and communications technologies (ICT) to

Manuscript received on April 7, 2016; revised September 23, 2016. This work is supported by the Twelfth five-year Research Project of Hunan Office for Education Sciences Planning of China: Research on the Mode of Multi-dimensional Interaction Teaching in Higher Vocational Colleges in Hunan (No. XJK014CZY050).

The authors are with School of Railway Operation and Management, Hunan Railway Professional Technology College, Hunan, China (e-mail: 635175235@qq.com, 1721695922@qq.com). teaching has reached new heights [1].

WorldUC (World University City) came into being against this background. It is a web e-learning platform featuring teaching blogs, web courses based on Web2.0 technology and cloud computing technology [2]. University and college teachers are required to build up their own teaching spaces on WorldUC with the aim of enhancing teaching and helping student with learning in the end.

\section{B. Micro Context}

\section{1) Institute}

The Business English Department that I have been working at was established in 2002 and now it has grown up to one of the best sections in this Chinese vocational college. It was conferred as the provincial teaching reform experimental major. This department is always needed to take the initiative to implement new teaching methods and keep pace with the latest teaching concepts, for example, business-process-orientation-based curriculum design and blogging teaching.

Concerning logistic conditions, there are 10 language learning laboratories to support language teaching, each of which is equipped with computers, a projector, a smart board and access to internet.

2) Teachers

Teachers in this department are required to do field work on a regular basis in business companies every summer holiday and to do interviews with graduates. The main purpose is to investigate and understand the needs of employees in this field and get to know the graduates' suggestions about teaching content.

In this case, teachers need to adapt or develop teaching materials to meet the up-to-date requirement from employees and fit in the advocacy of tech-enhanced teaching by the institute. Most teachers have participated in compiling and editing the in-house teaching course books, and some of the books have even been published. Every teacher was asked to set up a teaching blog on WorldUC and apply it to teaching.

\section{3) Learners}

The target learners are Business English major students. They are adult learners basically aged between 18 and 20 years old with an intermediate English level. They expect to work in international business field after the completion of study, so their learning needs can be defined as learning practical, professional-oriented and work-related knowledge for the future profession.

All of the students have a basic command of manipulating the computer and accessing the internet with regard to learning in the era of ICT. They are allocated to accounts of the college-based platform. They are able to interact and discuss with peers and teachers on line, finish tasks as a group 
or individually and submit the reports to teachers' blogs.

\section{4) Business English writing}

Business English Writing (BEW) is the compulsory course of this major which aims to help students with different kinds of business writing. Students will deal with e-mails, plans, reports, letters, minutes, and so on.

This course starts from the first year of the program (normally a 3-year program) and runs a whole academic year. Both formative and summative assessment are employed in students' evaluations. In formative assessment, students are assessed by a final writing exam. In terms of formative assessments, students are evaluated during the study process. The focus is on students' engagement, attitude and competence of working individually or collaboratively.

Currently, most students have realized the importance and practicality of business writing. This recognition is partly influenced by the feedback of graduates, partly due to business writing; as such it is a compulsory course for them. However, being unparalleled with the crucial status of learning writing, students generally appear to have a somewhat low interest and motivation.

\section{Pedagogic Rationale}

\section{A. Business English}

With economic globalization and the booming of international business and trade, business communication and using English as the main language for business have increased significantly, which has given a boost to the development of Business English. Business English is within the scope of ESP (English for specific purpose) from pedagogical perspective [3], which determines its distinctive characteristics. These characteristics include based on learners' needs and their final aims, vocational and professional orient, the focus on learning from real-life business scenarios. As Harding puts "As English gathers momentum as the main language of international communication, it is perceived as the language of career opportunity, so the pressure grows for teaching to be more directly employment-related." [4].

In terms of Business English subject content, knowledge of English and business skills are necessary for a solid foundation to guarantee an appropriate course of Business English. Therefore, the teaching of Business English should be cross-disciplinary and the knowledge of associated fields should be covered as well rather than simply emphasizing on language itself [5]. In addition, specialized terminologies, concordance and genre are used in Business English.

Second, in the era of information, the application of Internet technologies in international transactions has led to the dramatic growth of Internet-based business. Meeting face-to-face is time-consuming and adding to costs in international business. Business people may resort to technology to bridge geographical distance [6]. Information technology (IT) has been used to support exchanges of goods, services, and information between corporations worldwide [7]. And some tech tools can make international business easy, such as, e-mails, internet-based communication technology, social networks, chat software, etc. Hence, how to apply the technology properly is also suggested to be part of the teaching content in business English.

From the perspective of teaching approaches, methodologies and techniques, nowadays, teachers tend to use computers and the Internet as a way to facilitate teaching and enhance students' learning. A huge amount of resources and information online are accessible freely by students and teachers. Technology can greatly enhance classroom instruction and the Internet is a learning tool that fits well in a Business English syllabus.

\section{B. Challenges of Teaching Business Writing}

As the core module in Business English program, the importance of business English writing has long been recognized. Experts in international trade and other business field hold the belief that business writing is one of the most important components in doing business. Researchers in English for Specific Purposes found that students have strong desire to acquire the skills of business writing in order to meet the requirements at their future workplace [8].

However, according to a survey, Li claimed that roughly 90\% participants (graduates) considered Business English writing to be the most difficult course in the program and half of them appeared to mechanically rely on a number of model samples provided by teachers to communicate with their business customers in the real workplace. How to inspire students' interest in writing and improve the teaching efficiency were addressed in the study [9]. And Monis \& Rodriques said that writing is often "a solo activity, done silently, involving physical effort and time-consuming"[10]. This may make it no attraction to learners or teachers as a classroom activity. In addition, writing is difficult, even in L1. There are "linguistic, psychological and cognitive problems involved, making teaching it and learning it a considerable challenge" [10]. Intellectually satisfying writing tasks are suggested for learners to make their writing more communicative. At last, they argued course books don't necessarily always help students develop writing. Teaching materials that provide relevant, real and communicative practice are needed, though few of these are reachable for the time being.

\section{Learning Theories (Theoretical Framework)}

This section explores theories of learning about how learning takes place in relation to the roles that they can play in supporting language learning, especially underpinning business English writing.

\section{1) Constructivism}

With regard to teaching writing, constructivism assumes that the learners' writing competence can be improved through some cognitive and interactive activities. For example, learners can explore online resources as scaffolding for follow-up writing under the appropriate instructions. Being appropriate implies the assigned task should be based on learner's current level of associated knowledge. Learners can publish and articulate their writing on the Internet, and both peers and instructors do comments as a way to make interaction [11]. This learner-centered approach promotes the learner's ability of self-exploration and creativity. As 
Alexander and Elena said that "the Internet helps to make English lessons more rewarding and encourages opening the new way to bring about creativity and enthusiasm for learning"[12]. Besides, cooperative and collaborative learning occurs when computer-assisted language learning (CALL) is applied to language teaching and learning [13].

Constructivists in education have stemmed from several psychologists and educators such as Jean Piaget, Lev Vygotsky and Jerome Bruner. Constructivism, as a learning paradigm, supports part of the theoretical and conceptual framework for the study [14].

Trial constructivism originated from Jean Piaget, which is considered as the root of constructivism, and the main principle of which is learner constructing knowledge actively rather than receiving it passively. On the basis of theory of Jean Piaget, psychologist Ernst von Glasersfeld, the founder of radical constructivism, claimed that knowing is a process that "learner dynamically adapts to variable interpretation of experience and the role of knowledge is determined by the cognitive needs of the learners" [14]. Therefore, the emphasis is placed on constructing individually.

In recent decades, constructivists have extended the focus to collaborative and social dimensions of learning. The Social constructivism and language theory of learning was pioneered by Lev Vygotsky [15]. He believes that psychological development is built upon social interaction and relationship, in terms of learning, apart from being impacted by individual construction, learners would be influenced by surroundings and environment [14]. From Vygotsky's, constructing, creating, inventing, and developing one's own knowledge and meaning are involved in the process of learning.

Basically, building on the concepts of scaffolding, the common thread links constructivist thoughts are that learners do not receive knowledge delivered from teachers passively, but rather actively internalize it and interpret information and construct new knowledge based on their existing (current or previous) knowledge [16]. This implies learners are able to process information that may be slightly above their current level by using what they know to bridge the gaps.

In constructivist classrooms, teaching is not a simple transformation of knowledge from teachers to students. Teachers become facilitators who provide basic information and organize activities to help learners discover their own understandings and draw the conclusions themselves [14].

\section{2) Content-based instruction}

Content-based instruction (CBI) refers to "an approach to second language teaching in which teaching is organized around the content or information that students will acquire, rather than around a linguistic or other type of syllabus." [17] Content-based instruction integrates language with content, viewing "language as a medium for learning content and content as a resource for learning and improving language." [18] And this grounds and underpins language for special purpose (ESP is its subfields) theoretically, as LSP leaners are a group of people who need to acquire content and real-world skills in order to carry out specific roles (e.g. business people, engineer) through the medium of a second language[17].

There are three main assumptions within CBI in terms of language learning [17].
- "People learn a second language most successfully when the information they are acquiring is perceived as interesting, useful, and leading to a desired goal.” (p. 209) In other words, it is motivation to learners, as the informational content is learner-related.

- 'Students learn best when instruction addresses students' needs." (p. 210). This indicates that within CBI, the selected teaching content should meet learners' needs. Thus, authentic materials that learners are likely to encounter in the real life are considered to be the starting point of developing a syllabus (macro-level) or a lesson plan (micro-level).

- "Teaching builds on the previous experience of the learners." (p. 211). Students' previous knowledge strongly backs up their current study, and they bring this knowledge and understand to classroom. For instance, the starting point in designing a theme-based lesson is what the students already know about the content.

CBI has a number of characteristics which make it particularly effective in language instruction. It offers many practical advantages for teachers and course designers. According to Brinton et al. [19], integrated teaching of the four language skills is one of the distinct features in content-based approach. For example, students are required to read authentic reading materials, to understand and interpret as well as evaluate the information in the employed materials, response can be done in speaking or writing afterwards. "It also recognizes that writing follows from listening, and reading, and thus requires students to synthesize facts and ideas from multiple sources as preparation for writing."

In addition, the findings of Pessoa et al. indicates that an effective content-based instruction class can encourage students' language use and development reflected in students' oral and written discourse, as well as their metalinguistic awareness[18]. Iakovos found that students' interest and engagement are stimulated, motivation is enhanced in content-based instruction classes.[20] Through investigating if there is any difference regarding students' language learning performance when taught through Content-based Instruction or Grammar-translation method (GTM), the lately empirical study conducted by Amiri \& Fatemi shows that CBI group outperformed the GTM one, which implies that if planned and adopted carefully, CBI can stimulate students' both problem solving ability and critical thinking, thus leading to higher language learning orientations [21].

\section{LESSON PLANS}

In light of my specific teaching context and referring to the above constructivism learning theory and the content-based instruction, technologies are considered to employ in the lesson design. As technology can provide opportunities for learners to extend their contact and use of English beyond the classroom; thus enables learners to make use of in- and out-of-class autonomous learning based on their interests and needs [22].

And at all times, the choice of the techniques and approaches made has been revolving around students' needs 
for their future professions or jobs.

The topic of the lesson I choose to present in this paper is a business introductory partnership letter, which is the first and foremost theme in business English writing.

\section{A. Need Analysis and Teaching Objectives}

Needs analysis is technically the perquisite for an appropriate course design in ESP, and its two main concerns are "Target needs (i.e. what the learner needs to do in the target situation) and learning needs (i.e. what the learner needs to do in order to learn)" [3].

Target needs refers to the target situation in terms of necessities, lacks, wants. "Necessities are the type of needs determined by the demands of the target situation, that is, what the learner has to know in order to function effectively in the target situation" [3] Lacks means the gap between learners existing knowledge and the necessities perceived. Wants is concerned with learners' wish and perceptions of needs, this is a subtle issue in analysis as learners' standing points vary and their needs are not necessarily valuable to some degree [23]. Learning needs indicates, in Hutchinson \& Waters' words, how learners get from "lacks (starting point) to necessities (destination)" [3].

Ideally, concerns from learners (students), the sponsors, the employers, the teaching organizations, are all necessary to be considered in need analysis. However, in this teaching design, analysis of necessities, lacks as well as learning needs are likely to be the main data source for establishing needs, and wants from students are not considered due to certain constraints.

On the basis of the above context introduction, needs in this teaching context can be defined.

Necessities: Most students will be doing import and export business after graduation. Writing a promising business introductory letter is the starting point to connect with prospective customers and develop a business relationship.

Therefore, students need to know how to write a good introductory letter in order to win customers, which is the core of business.

Generally, a good introductory should demonstrate how the writer understands the reader's needs and desires, and it should also tell the recipient why becoming your customer is a smart move.

Lacks: Business English writing starts in the first year of the program, and writing introductory letter is the first session and topic of the module. Therefore, all knowledge related to business English is new to students. They know little about how a formal Business letter should be written.

Hence, students are expected to have a good command of writing an appropriate introductory letter in certain settings; such as correct format, proper words usage, informative details. In the meantime, their awareness of collaborative learning is suggested to be enhanced through the means of blog platform.

\section{B. Design Rationale: Technology-enhanced language teaching}

\section{1) Why WebQuest}

In my design, I am going to apply WebQuest, my own teaching blog, and a concordance to provide students with input and help them write appropriate business English letters. Abbreviations and Acronyms

WebQuest is "an inquiry-oriented activity in which some or all of the information that learners interact with comes from resources on the internet, optionally supplemented with videoconferencing" [24]. That is to say, WebQuests are Internet-based technological applications in which inquiry-oriented activities are created, based on which, students could follow steps to complete a task by acquiring knowledge from the internet [25].

WebQuests draw from theories of language learning and underline pedagogical meanings. A web quest itself can be regarded as a process of scaffolding and a web quest can be conceptualized as a way of providing comprehensible input for the learners. A WebQuest is "a scaffold learning structure" that allows students to use links to reach essential resources on the internet and gives authentic tasks to motivate students "investigation of a central, open-ended question, development of individual expertise and participation that attempts to transform newly acquired information into a more sophisticated understanding" [26].

And it also fits in well with principles of constructivism in language teaching, as Tuan said, "a WebQuest is in fact a constructivist lesson format. The key concept of this approach is that learning is an active process of creating rather than acquiring knowledge" [26], and the main focus of teaching is students. Using WebQuest, students are able to learn by constructing their perceptions which results in understanding and the processing information from their own experiences [27].

A WebQuest is especially suited to content-based language learning as well. Stoks suggested that "WebQuests offer good internet-based language learning opportunities because they provide learners with exposure to authentic material, meaningful content and possibilities for real communication in the target language.” [28]. Pérez Torres added, WebQuests are activities that meet the requirements of the three essential conditions for language learning "exposure, use and motivation" [26]. WebQuest are claimed to be helpful to language learners in the light of linguistic perspectives include (1) exposure to authentic materials (2)meaningful content and (3) possibilities for real communication in the target language [25].

WebQuests are increasingly becoming popular in English reading and writing teaching, because they provide learners authentic and collaborative tasks. When students do the WebQuest tasks, they may find the information firstly, then read and write about it, and complete the task at last. As Halat stated that WebQuest may lead to increased student motivation.

\section{2) Why teaching blogs}

Blogs (stem from web log) are "frequently modified webpages containing individual entries displayed in reverse chronological sequence" [29].

Nowadays, Blogs has been widely employed in language learning and teaching, and many teachers have set up 'teaching blogs' to interact with students and help them with learning. There is a consensus in pedagogic meaning of using blogs is: 
Blogs lend themselves to easily accessible publication and dissemination of student writing, to information-sharing, to the collaborative construction of meaning, and, significantly, to learner control.

A blog is an effective student-centered learning tool [30]. It allows student writers to interact with readers (peers or teachers) by commenting on each other's posts. The interactive readership is likely to be stimulus to student bloggers to enhance their writing skills and positive attitudes. It also functions a text recorder through which the writers and readers can track all the contributions they have been making, the footprint itself they made in the blog presents a learning process.

Many researchers have found that blogging teaching can boost interactions between language student writers by providing them with a platform to express themselves freely, in the meantime, strengthen their writing skills and motivate them to write [31]. And a more recent empirical study by Lin has confirmed that it is worthy being recommended that blog is helpful to improve students' writing skills and enhance their learning attitudes towards writing [31].

\section{3) Language corpus and concordancers}

Meyer said, language corpora (concordancers) are collections of "texts or parts of texts upon which some general linguistic analysis can be conducted," [32] and the output (a list of examples) of whose is called a concordance, to be more in detail, it is "an index of all the words in the corpus along with their immediate linguistic contexts and some information about the frequency and location of each" [33].

Corpora are becoming "an easily accessed source of language input, potentially provide rich and authentic lexico-grammatical data for language learning." [34] A number of these online corpus-based resources are free to access, and they are becoming more readily used and functional. For example, language teachers are able to use corpora to make exam paper to assess students' competence in using vocabulary in a certain context, and teachers can develop hypertext resources as teaching materials as well, while Students can look up word meanings, work out the correct collocations and test their ability to detect grammatical errors, most importantly, corpora are accessible for students working independently.

Concordances can give learners a clear idea of how language works, as it notices learners that the gap between the way they use the language and the experts do. This can be of particular function in assisting students with writing, as the authentic corpus gives explicit information about typical lexical and syntactic collocations, which is helpful to enhance the appearance of native-like fluency in term of writing.

\section{Planning the Lesson}

Lesson planning and development serve invaluable function in the learning process. A planned lesson acts as a guide to the teacher to do instructional activities.

Overall, this plan is designed with webQuest. The main four components are included: introduction, aims, tasks and process, follow up exercise. Generally, it introduces information through readings (writing samples) followed by exercises, and ends with written assignments. The materials used are online resources suggested by the teacher (me), and the topic chosen covers knowledge and skills that students need for future work. The detailed rationale for the design of each section and how it is working to achieve the teaching goal will be discussed in the following part.

The introduction provides students with the basic information about the importance of writing a good business introductory letter, and the key role this letter plays in starting a business relation. This is likely to encourage students to pay more attention to learn it well. Then section 2 tells what students are required to do after this session, which makes a clear idea of the purpose of learning to learners.

Next, as the main part of the plan, section 3 (tasks and process) consists of 5 steps. Considering students' lack of knowledge on business introductory letter, Step 1 introduces general information about introductory business letter.It involves what the letter refers to, what is the difference between this letter and other personal letters, and what features it has, what the components are. Students are able to acquire all the knowledge by clicking the links suggested.

As the follow up study of step 1, step 2 gives samples and shows students what the real letters look like.( WebQuests are used here as well) To some extent, this part also indicates authenticity and comprehensible input because it covers genuine examples of the writing instructions and writing products which might be helpful for students as the examples are worth being references in their own writings. Due to the fact that students' English level in this class vary, some samples with Chinese translation are given as well to help some students have a better understanding of the letters.

In step 3, students start to do situated learning. By given authentic materials via links (online resources from the companies' official websites).Students browse the websites and work on filling out the translation exercises. Concerning the blank filling exercise, one consideration of this design is to have students do intensive reading with this specific learning task, the other is that it may more or less echo the information needed in the writing assignment, which students are likely to get some clues for writing to some degree. Providing a translation exercise aims to firm up students' comprehension of material reading, though learners' might encounter some specific terms, so the use of paper dictionary, electronic dictionary or English-Chinese Concordancers are recommend to help learners work out the difficulties. In general, these two exercises are not quite hard for learners at this particular level and attempt to let learners focus on some particular parts of the input. This process is comprehensible and effective from my perspective, which is possible to lay the basis for the subsequent writing practice.

Step 4 is a try-out section. Students are set to be the representatives of Hangzhou Paradise Umbrella Group Co., Ltd and wish to cooperate and establish business relations with Walmart, an American multinational retail corporation. The task for learners is to write an introductory letter to Walmart to express the desire to establish business relations. Frankly speaking, this task might seem to be funny and unrealistic; indeed, it is not going to happen in the real world. However, this exaggerated scenario may shed some lights on how to find a potential business partner and write a proper introductory letter in accordance with partner's needs by 
means of online resources( especially, websites), and the process itself is what students might experience in their future work. Thus, I would prefer to define the task is semi-authentic. In consideration of the specific genre of business English writing, I advise students to refer to Online Business Letter Corpus KWIC Search (an online concordancer which is especial concerned with business letters) to ensure the accuracy of language use.

In the last step, students are requested to post their writing on my teaching blog. I am going to make comments, so will other peer classmates. Interactions between teachers and students and communications amongst peers can be highly inspired.

The plan ends with a follow-up exercise, with the purpose of consolidating students' study in this session. Students are expected to make their own study plan (with the support of WebQuest) and based on the personalized introductory letter, which might be challenging but beneficial a lot.

\section{EVALUATION AND REFLECTION}

I tried out this lesson plan with 2 college students in China. Lesson plan was sent to them via email respectively at 9 am, Nov. 20th, 2015. There were no more instructions to students other than following steps in the design. Students' writings were uploaded onto my teaching blog 3 hours later (as the teaching plan required), then their feedback on the plan and mutual-comment on writings were posted as well later on that day.

\section{Students' Feedback: (Translation Version)}

Student 1: I found I had no idea what to do at the beginning After all, I have never learned in this way before. I could not understand some terminologies in online references which were suggested by teacher to read, and some instructions given in the plan were not actually helpful or useful for my writing. Nevertheless, the concondancer (student said it was a new online dictionary) is quite interesting, I think I will keep using it for Business English learning. I like this way to study, as it can improve our autonomy in study, enlarge our vocabulary, get in touch with the real business world, (authentic materials and real business scenarios) as well as speed up my reading.

Student 2: This is totally a new thing to me. I was very excited when I was browsing the official website of Hangzhou Paradise Umbrella Group Co., Ltd and Walmart. I felt like I was the staff in the Hangzhou Corporation instead of a student in the college. However, I found I had difficulties in reading articles ( by clicking the links the teacher gave in the plan), as lots of terms related to umbrellas were big barriers for me to understand. Apart from this, overall, I like the way to write business letters, and online readings are better than the ones in textbook, as they are authentic. It can encourage me jump into a real business situation and do something valuable rather than just finish my school work. And I think it is very helpful for my reading as well.

Regarding students' writings (the introductory letters they post), on the whole, they meet the learning objectives of the lesson. They have a basic command of basic knowledge of how to write an introductory letter in terms of letter format and business letter genre. However, the use of samples should not be abused since students have a tendency to copy word for word. Writings turn out to be quite identical, to some extent, it implies students were demotivated in terms of creativity. So I would argue that it is vital to choose appropriate internet resources when applying WebQuest to writing.

Looking back at the whole process and reflecting on my lesson plan, suggestions for improvement could be as follows:

- Guidance are necessary before students start to work on tasks in WebQuest. Students should have a clear idea about what they need to do in order to complete the tasks well.

- Less readings in one writing session. Concerning my lesson plan, there are more than 10 online readings and some of them are not strongly relevant to the assigned writing task, which added to students' study load and decreased their interest. In other words, selecting proper amount and ensuring the quality of online articles are the top priority.

- Concerning peers' comments written on teaching blog, one of the 2 students just simply wrote "well", which lost the meaning of peers' collaboration. In this case, I would suggest certain criteria can be made to frame the comments. Nonetheless, flexibility and frame should coexist.

\section{CONCLUSION}

The utilization of Web-based tools in business English writing has been discussed and practiced in this study. The outcomes reveal generally students have a positive view on adopting WebQuest, along with other technological tools in Business English writing. Authentic learning materials, interactive and collaborative learning can enhance students' learning process. Additionally, students' study interest and motivation are stimulated, as it prepares students for tackling professional problems in real life. They can apply what they have done in the classroom to the future workplace, which makes writing lessons more rewarding.

Nonetheless, arranging an effective Business English writing teaching is not easy. Implementing Web-based and ICT-enhanced teaching demands proper ways of selecting and adapting appropriate materials from the vast and complex internet. New ideas of classroom management as well as teachers' up-to-date knowledge of teaching techs, and all seem to be big challenges to teachers nowadays.

\section{REFERENCES}

[1] D. P. Yang, "Upgrading educational models pushing through educational reform at the institutional level," Chinese Research Perspectives on Educational Development; Leiden: Koninklijke Brill NV, pp. 3-30, 2013.

[2] L. Chen and H. Lu, "On construction of PE teaching cloud hosting based on the technology of cloud computing," The Chinese Journal of ICT in Education, vol. 23, pp. 88-92, 2012.

[3] T. Hutchinson and A. Waters, English for Specific Purpose: A Learning - Centered Approach, Cambridge: Cambridge University Press, 1987.

[4] K. Harding, English for Specific Purposes, Oxford: Oxford University Press, 2007.

[5] A. Teodorsescu, "Traditional vs. modern approaches in business English teaching in the economic field," Knowledge Horizon, 2013. 
[6] C. Cristian and O. Talai, "Communication technology in international business-to-business relationships," The Journal of Business \& Industrial Marketing, vol. 29, no. 1, pp. 24-33, 2014.

[7] Q. Z. Dai and R. J. Kauffman, "Business Models for Internet-based B2B Electronic Markets," International Journal of Electronic Commerce, vol. 6, no. 4, pp 41-72, 2002.

[8] J. Chen, "Using genre of linguistic approach to teaching business writing in the vocational and technical College," Literatures, vol. 2, pp 53-55, 2012.

[9] X. P. Li, "Systematic teaching design of communicative context in business English writing in Chinese context," Studies in Literature and Language, vol. 8, no. 1, pp. 24-31, 2014.

[10] M. Monis and M. V. Rodriques, "Teaching creative writing in English language classroom," Indian Streams Research Journal, vol. 2, no. 10 , pp. 1-6, 2012.

[11] S. A. Walker and G. White, "Technology enhanced language learning Connecting theory and practice," Oxford Handbooks for Language Teachers, Oxford: Oxford University Press, 2013.

[12] I. C. Alexander and A. D. Elena, "The breakthrough of the internet to empower ESP teaching and learning at Tomsk Polytechnic University," Global Journal of English Education, vol. 9, no. 2, 2005 , pp. 129-136.

[13] M. MaCabe, "Lesson from the field: Computer conferencing in higher education," Journal of Information Technology for Teacher Education, vol. 7, no. 1, pp. 71-84, 1998.

[14] Liu et al, "Evolution of Constructivism," Contemporary Issues in Education Research, vol. 3, no. 4, pp. 63-65, 2010.

[15] M. P. Omoto and W. J. Nyongesa, "Content-based instruction: A study of methods of teaching and learning English in primary schools in Butula district," International Journal of Business and Social Science, vol. 4, no. 5, pp. 236-245, 2013

[16] L. Mbati, "Online social media applications for constructivism and observational learning," International review of research in open and distance learning, vol. 14, no. 5, pp.166-185, 2013.

[17] J. C. Richards and T. S. Rodgers, Approaches and Methods in Language Teaching, 2001, (2nd edition), Cambridge: Cambridge University Press.

[18] S. Pessoa et al., "Content-based instruction in the foreign language classroom: a discourse perspective," Foreign language annals, vol. 40 no. 1, pp. 102-121, 2007.

[19] D. Brinton, M. Snow, and M. Wesche, Content-Based Second Language Instruction, New York: Newbury House, 1989

[20] T. Iakovos et al., "Content-based Instruction in the teaching of English as a foreign language," Review of European Studies, vol. 3, no. 1, pp. $115-121,2011$

[21] M. Amiri and A. H. Fatemi, "The impact of content-based instruction on students' achievement in ESP courses and their langague learning orientation," Theory and Practice in Language Studies, vol. 4, no. 10, pp. 2157-2167, 2014.
[22] J. C. Richards. (2015). Professor Jack, C. Richards's official website. [Online]. Available: http://www.professorjackrichards.com/category/teaching/

[23] F. Chambers, "A re-evaluation of needs analysis in ESP," The ESP Journal, vol. 1, no. 1, pp. 25-33, 1980 .

[24] B. Dodge. (1997). Some thoughts about Webquests. [Online] Available:

http://mennta.hi.is/vefir/danska/webquest1/Some\%20Thoughts\%20A bout\%20WebQuests.htm

[25] Z. Kocoglu, "Web quests in EFL reading/writing classroom," Procedia - Social and Behavioural Sciences, vol. 2, no. 2, pp. 3524-3527, 2010.

[26] L. T. Tuan, "Teaching reading through WebQuest," Journal of Language Teaching and Research, vol. 2, no. 3, pp. 664-673, 2011.

[27] M. Grant. (2002). Getting a grip on project-based learning: theory, cases and recommendations. Meridian: A Middle School Computer Technologies Journal. [Online]. 5(1). Available: http://www.ncsu.edu/meridian/win2002/514/project-based.pdf

[28] G. Stoks. (2002). WebQuest: Task-based learning in a digital environment. Babylonia. [Online]. Available: http://babylonia.ch/fileadmin/user_upload/documents/2002-1/Baby1_ 02Stoks.pdf

[29] Herring et al. (2004). Women and children last: The discursive construction of weblogs. Into the Blogosphere: Rhetoric, Community and Culture of Weblogs. [Online]. Available: http://blog.lib.umn.edu/blogosphere/

[30] D. Churchill, "Educational applications of web 2.0: Using blogs to support teaching and learning," British Journal of Educational Technology, vol. 40, pp. 179-183, 2009.

[31] M. H. Lin et al., "Blogging a journal: Changing students' writing skills and perceptions," ELT Journal, vol. 68, no. 4, pp.422-431, 2014

[32] C. F. Meyer, "English corpus linguistics," An Introductio,. Cambridge: Cambridge University Press, 2002.

[33] T. M. Cobb. (1997). From concord to lexicon: development and test of a corpus-based lexical tutor. [Online]. Available: http://www.collectionscanada.gc.ca/obj/s4/f2/dsk3/ftp04/nq25913.pd $\mathrm{f}$

[34] M. Franken, "The nature and scope of student search strategies in using a web derived corpus for writing," The Language Learning Journal, vol. 42, no. 1, pp.85-102, 2014.

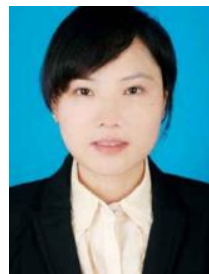

Dan Li was born in Hunan, China, in 1981. She graduated with a BA degree in English literature from Mid-south University, Hunan, China, in 2000. She got her first MA degree in higher education from Hunan Normal University, China, in 2007. And she completed her second master study in teaching English as a Second Language (TESOL) from University of Leeds, Leeds, the UK, in 2015. Her areas of interest are teaching ESP courses, teaching material development, EFL teacher education. 